\section{Polymorphism of the estrogen receptor $\beta$ gene is related to infertility and infertility- associated endometriosis}

\author{
O polimorfismo do gene do receptor $\beta$ de estrógeno está relacionado \\ com infertilidade e endometriose associada à infertilidade
}

Karina Zulli', Bianca Bianco', Fernanda Abani Mafra', Juliana Souto Teles'', Denise Maria Christofolini', Caio Parente Barbosa'
1 Divisão de Patologia Ginecológica e Reprodução Humana, Departamento de Ginecologia e Obstetrícia, Faculdade de Medicina do ABC (FMABC), Santo André, SP, Brazil identified by RFLP-PCR (Restriction Fragment Length Polymorphism - Polymerase Chain Reaction). Results: Genotypes GG, GA and AA of the ER $\beta$ gene presented frequencies of $60.3 \%$, $38.2 \%$ and $1.5 \%$, respectively, in the women with endometriosis ( $p<0.0022$ ). Of the infertile women without endometriosis, $63.8 \%$ presented the normal homozygous genotype GG, 30.4\% the GA heterozygous genotype, and $5.8 \%$ the homozygous mutated genotype $A A(p<0.0275)$. In the control group, $77.5 \%$ presented the normal homozygous genotype GG, $21.1 \%$ the heterozygous genotype $\mathrm{GA}$, and $1.4 \%$ the homozygous mutated genotype $\mathrm{AA}$. Conclusion: The data suggest that the estrogen receptor $\beta$ gene $(E R \beta)+1730 \mathrm{G} / \mathrm{A}$ polymorphism can be associated with risk of infertility and endometriosis-associated infertility. Arq Bras Endocrinol Metab. 2010;54(6):567-71

\title{
Keywords
}

Endometriosis; estrogen receptor $\beta$; estrogen; infertility; polymorphism

\section{RESUMO}

Objetivo: Determinar a frequência do polimorfismo +1730 G/A do gene do receptor beta de estrógeno $(E R \beta)$ em mulheres inférteis com e sem endometriose e controles. Sujeitos e métodos: Estudo caso-controle que incluiu 136 mulheres com endometriose, 69 mulheres sem endometriose e 209 mulheres férteis como controles. O polimorfismo $E R \beta+1730 \mathrm{G} / \mathrm{A}$ foi identificado por RFLP-PCR (Restriction Fragment Length Polymorphism - Polymerase Chain Reaction). Resultados: Os genótipos GG, GA e AA do polimorfismo $E R \beta+1730 \mathrm{G} / \mathrm{A}$ apresentaram frequência de $60,3 \%, 38,2 \%$ e $1,5 \%$, respectivamente, nas mulheres com endometriose $(p=0,0022)$. Das mulheres inférteis sem endometriose, $63,8 \%$ apresentaram o genótipo homozigoto normal GG, $30,4 \%$ o genótipo heterozigoto $G A$ e $5,8 \%$ o genótipo homozigoto mutado $A A(p=0,0275)$. No grupo controle, os genótipos GG, GA e AA apresentaram frequência de $77,5 \%, 21,1 \%$ e 1,4\%. Conclusão: Os dados sugerem que o polimorfismo $E R \beta+1730 \mathrm{G} /$ pode estar associado ao risco de infertilidade e infertilidade associada à endometriose. Arq Bras Endocrinol Metab. 2010;54(6):567-71

Descritores

Endometriose; receptor $\beta$ de estrógeno; estrógeno; infertilidade; polimorfismo

Correspondence to: Bianca Bianco

Faculdade de Medicina do ABC Av. Príncipe de Gales, 821 09060-650 - Santo André, SP, Brazil

bianca.bianco@hotmail.com

Received on Mar/10/2010 Accepted on July/6/2010

\section{INTRODUCTION}

$\mathrm{E}$ ndometriosis is a steroid-dependent condition in which a tissue that is histologically similar to the endometrium with glands and stroma grows outside the uterine cavity and becomes implanted in tissues and organs such as the Fallopian tubes, ovaries, peritoneum, 
colon, the retrovaginal region and the bladder (1), being able to cause pelvic pain, dysmenorrhea and infertility (2). Endometriosis affects $3 \%-10 \%$ of women in their reproductive years and $20 \%-50 \%$ of women with infertility (3). Susceptibility to endometriosis depends on a complex interaction of immunologic, genetic and hormonal factors (4). Many aspects of the female reproductive function are strongly influenced by genetic factors, and numerous studies have attempted to identify susceptibility genes for disorders affecting female fertility such as endometriosis (5).

The estrogen receptor (ER) plays an important role in mediating estrogen action on target tissues. There are two isoforms of estrogen receptors, ER $\alpha$ and $\mathrm{ER} \beta$, which are encoded by different genes (6). Estrogen receptor $\alpha$ has a higher affinity for estrogen and is the predominant form in normal endometrium. Because large amounts of ER $\beta$ messenger ribonucleic acid (mRNA) are found in ovaries and granulosa cells, ER $\beta$ is likely to play a role in the ovulatory function (7). Previous studies have demonstrated that both ER $\alpha$ and ER $\beta$ are expressed in human endometriotic tissues (8), but the distribution of the isoforms is different between eutopic endometrium and ovarian endometriotic tissues (9).

Bianco and cols. (10) studied infertile women with endometriosis and controls for the $+1730 \mathrm{G} / \mathrm{A}$ polymorphism in the ER $\beta$ gene (rs4986938) and found that this polymorphism was associated with an increased risk of developing endometriosis, regardless of the stage of the disease. However, all patients with endometriosis studied were infertile.

Thus, the objective of the present study was to determine whether the $E R \beta$ gene $+1730 \mathrm{G} / \mathrm{A}$ polymorphism is actually associated with endometriosis and/or infertility.

\section{SUBJECTS AND METHODS}

One hundred and thirty six infertile women with endometriosis (mean age: $33.7 \pm 4.01 \mathrm{yr}$.) from the Endometriosis Outpatient Clinic of the ABC School of Medicine (FMABC) were studied. Women with endometriosis diagnosed by laparoscopy were selected and classified by histological criteria, according to the American Society for Reproductive Medicine (11). In the endometriosis group, $52.2 \%$ of the patients $(71 / 136)$ had minimal or mild (stage I/II) and $47.8 \%(65 / 136)$ had moderate or severe (stage III/IV) endometriosis. Sixty-nine infertile women without endometriosis (mean age: $34.8 \pm 5.1 \mathrm{yr}$.) were screened at the Human
Reproduction Service of FMABC. All women who had a partner with any infertility factor were excluded from the study. For the control group, 210 women (mean age: $39.8 \pm 4.5$ yr.) who had been submitted to tubal ligation, which allowed confirming the absence of endometriosis, were selected from the Family Planning Outpatient Clinic of FMABC.

The cause of infertility was investigated according to the minimum propedeutic procedures for infertile couples: hormone and chemistry profile, serum testing, testing for sexually transmitted diseases, imaging examinations, investigation of genetic and/or immunologic abnormalities, hysterosalpingography, hysteroscopy, laparoscopy (laparoscopy was performed on all women up to 36 years old and also in patients over 36 whenever there were symptoms or abnormalities on imaging examinations), and semen analysis. Patients with endometriosis who did not achieve pregnancy after at least six natural or induced cycles following laparoscopy were considered infertile. All women whose partners had any male factors associated with infertility were excluded from the study.

Clinical data and peripheral blood samples were collected only after explaining the objectives of the study and obtaining signed informed consent, as approved by the Research Ethics Committee of the ABC School of Medicine.

Peripheral blood was collected from each patient and control in an EDTA-containing tube. Genomic DNA was extracted from peripheral blood lymphocytes using an Illustra blood genomicPrep Mini Spin Kit (GE Healthcare Life Sciences, USA), according to the manufacturer's instructions.

Molecular analysis of the ER $\beta$ gene (MIM 601663/ Genbank ID 2100) +1730 G/A polymorphism (rs4986938) was performed according to the protocol of Lee and cols.. (2007) (12), with modifications. The primers used were: 5'-TTTTTGTCCCCATAGTAACA-3' (forward) and 5' -AATGAGGGACCACAGCA-3' (reverse). PCR reaction was carried out in a final volume of $25 \mu \mathrm{L}$, containing $\mathrm{IX}$ buffer, $2.5 \mathrm{mM}$ of $\mathrm{MgCl}_{2}, 0.1 \mathrm{mM}$ of each dNTP, $50 \mathrm{nM}$ of each primer, IU Taq Polymerase (Invitrogen), and 200 ng of DNA. Amplification was performed with an initial denaturation step at $95^{\circ} \mathrm{C}$ for 7 minutes, followed by 35 cycles of: denaturation at $95^{\circ} \mathrm{C}$ for 45 seconds, annealing at $53^{\circ} \mathrm{C}$ for 1 minute, extension at $72^{\circ} \mathrm{C}$ for 1 minute, and a final extension step at $72^{\circ} \mathrm{C}$ for 7 minutes. PCR products were analyzed for restriction fragment length polymorphism (RFLP) by using $5 \mathrm{U}$ of AluI restriction 
enzyme at $37^{\circ} \mathrm{C}$ overnight and visualized in $2 \%$ agarose gel stained with ethidium bromide under UV light.

A G/A exchange at nucleotide 1730 in exon 8 introduces a recognition site for AluI. Digestion by AluI produces one band of $307 \mathrm{bp}$ in the normal ER $\beta$ sequence (GG); three separate bands of 307,240 , and $67 \mathrm{bp}$, respectively, in the heterozygous polymorphism (GA); and two separate bands of 240 and 67 bp, respectively in the homozygous polymorphism (AA).

A random subset ( $20 \%$ of samples) was repeated by qPCR to verify the results. Detection of the $E R \beta+1730$ G/A polymorphism (rs4986938) was made by TaqMan real-time PCR, using the Rotor-Gene Q 6 plex Platform (QIAGEN, Valencia, CA, USA). Commercially available Taqman primers and probes for $E R \beta+1730 \mathrm{G} / \mathrm{A}$ polymorphism were used (C_11462726_10, Applied Biosystems $^{\circledR}$, Foster City, CA, EUA). Assays were performed with Taqman Universal Master Mix (Applied Biosystems $^{\circledR}$, Foster City, CA, EUA), with 50 ng of DNA per reaction. PCR conditions were as recommended by the manufacturer: initial denaturation at $95^{\circ} \mathrm{C}(15 \mathrm{~min})$, followed by 40 denaturation cycles at $95^{\circ} \mathrm{C}(15 \mathrm{sec})$, and a final annealing/extension cycle at $60^{\circ} \mathrm{C}(1 \mathrm{~min})$.

The chi-square test was used to compare allele and genotype frequencies between groups and to estimate the Hardy-Weinberg equilibrium. Statistical tests of significance and $\chi^{2}$ analysis were carried out using SPSS for Windows 8.0 (SPSS, Inc., Chicago, IL). All $p$-values were two-tailed and $95 \%$ confidence intervals (CIs) were calculated. A $p$-value $<0.05$ was considered statistically significant.

\section{RESULTS}

In the women with endometriosis, the frequencies of genotypes GG, GA and AA of the $E R \beta$ gene +1730 $\mathrm{G} / \mathrm{A}$ polymorphism were $60.3 \%(82 / 136), 38.2 \%$ (52/136) and $1.5 \%(2 / 136)$, showing a significant difference in the genotype distribution related to control group $(\mathrm{p}=0.0022)$. Among the infertile women without endometriosis, $63.8 \%$ (44/69) presented the normal homozygous genotype GG, $30.4 \%(21 / 69)$ the heterozygous genotype GA, and 5.8\% (4/69) the mutated homozygous genotype AA, also showing a statistical difference in genotype distribution $(\mathrm{p}=0.0275)$. In the control group, $77.5 \%(162 / 209)$ presented the normal homozygous genotype GG, 21.1\% (44/209) the heterozygous genotype GA, and $1.4 \%(3 / 209)$ the homozygous mutated genotype AA (Table 1 ).

Regarding the alleles, allele $\mathrm{G}$ was present in $79.4 \%$ of the patients with endometriosis, in $79.0 \%$ of the infertile women without endometriosis and in $88.0 \%$ of the controls, whereas allele A was present in $20.6 \%$, $21.0 \%$ and $12.0 \%$, respectively, of the patients with endometriosis $(\mathrm{p}=0.003)$, infertile women without endometriosis $(\mathrm{p}=0.0124)$ and controls (Table 1$)$.

The control group and infertile patients without endometriosis were in Hardy-Weinberg equilibrium (HWE). The group of infertile patients with endometriosis was not in HWE.

\section{DISCUSSION}

Estrogen produced in the ovaries controls the secretion of pituitary gonadotropins and is a key intraovarian modulator of ovarian activity, mainly affecting the function of granulosa cells. It contributes to oocyte maturation, fertilization, and embryo quality. Moreover, estrogen plays a crucial role in embryonic and fetal development, influencing secondary sexual characteristics, the reproductive cycle, fertility and maintenance of pregnancy. Additionally, it also plays a regulatory role in endometrial cell growth and differentiation (13).

Studies of the receptors' tissue distribution and expression pattern indicate that ER $\alpha$ has a broad expression pattern, whereas ER $\beta$ has a more focused pattern with high levels in the ovary, prostate, epididymis, lung, and hypothalamus (14). However, the exact physiological responses attributable to each receptor are unknown.

$\mathrm{ER} \alpha$ is found in all human reproductive tissues. Its role in reproduction has been elucidated by studies on male and female ER $\alpha$ knockout mice that showed com-

Table 1. Genotype and allele frequencies of the $E R \beta+1730 \mathrm{G} / \mathrm{A}$ polymorphism in endometriosis patients and controls

\begin{tabular}{|c|c|c|c|c|c|c|c|c|c|c|}
\hline \multirow{2}{*}{ Population studied } & \multirow{2}{*}{$\mathbf{n}$} & \multicolumn{3}{|c|}{ Distribution of genotypes } & \multirow{2}{*}{ p-value ${ }^{a}$} & \multirow{2}{*}{ p-value ${ }^{b}$} & \multicolumn{2}{|c|}{ Alleles } & \multirow{2}{*}{ p-value ${ }^{a}$} & \multirow{2}{*}{ OR $(95 \% \mathrm{Cl})$} \\
\hline & & GG & GA & AA & & & G & A & & \\
\hline Infertile women with endometriosis & 136 & $82(60.3)$ & $52(38.2)$ & $2(1.5)$ & 0.0022 & 0.1496 & $216(79.4)$ & $56(20.6)$ & 0.003 & $1.91(1.26-2.89)$ \\
\hline Infertile women without endometriosis & 69 & $44(63.8)$ & $21(30.4)$ & $4(5.8)$ & 0.0275 & & $109(79.0)$ & $29(21.0)$ & 0.0124 & $1.96(1.18-3.24)$ \\
\hline Control group & 209 & $162(77.5)$ & $44(21.1)$ & $3(1.4)$ & & & $368(88.0)$ & $50(12.0)$ & & \\
\hline
\end{tabular}

${ }^{a}$ versus controls; ${ }^{\text {b }}$ versus infertile women without endometriosis; OR: odds ratio; Cl: confidence interval. 
plete infertility (15). The female mice were infertile because they were anovulatory, had altered pituitary gonadotropin concentrations and impaired uterine response to estrogen (16). Recently, polymorphisms in ER $\alpha$ have been associated with male and female infertility (17).

A study performed in female ER $\beta$ knockout mice has confirmed that ER $\beta$ is essential for normal ovulation efficiency but not for sexual differentiation, fertility, or lactation (18), and several reports have demonstrated that ER $\beta$ proteins can be detected in multiple cell types throughout the female reproductive system (13). In fact, ER $\beta$ proteins are detected in human placenta (19) and in multiple cell nuclei within the glands and stroma of the human endometrium, where the intensity of immunostaining varies depending upon the stage of the menstrual cycle (20). One cell type that might represent a target for estrogen action mediated exclusively by ER $\beta$ is represented by the endothelial cells of the endometrium. These cells are ER $\beta$-positive and synthesize low (21) or even undetectable (22) amounts of ER $\alpha$. Studies on endothelial cells isolated from human endometrium have shown that exposure to E2 stimulates endothelial cell proliferation (21). The human endometrium also contains a subset of uterine-specific natural killer ( $\mathrm{uNK}$ ) cells that plays an important role(s) in decidualization, menstruation and implantation.

The ER $\beta$ gene is located on chromosome $14 \mathrm{q} 22-24$ (23). Systemic mutation screening of the coding region and part of the 50 and 30 regions of the $E R \beta$ gene revealed two common single nucleotide polymorphisms: $\mathrm{G} / \mathrm{A}$ exchange at nucleotide 1730 in the 30 untranslated region in exon 8 , and a silent $1082 \mathrm{G} / \mathrm{A}$ transition in exon 5 (24). The functional significance of the $+1730 \mathrm{G} / \mathrm{A}$ polymorphism remains to be clarified. Although $+1730 \mathrm{G} / \mathrm{A}$ polymorphisms in the $E R \beta$ gene do not lead to amino acid changes in the ER $\beta$ protein, it is possible that these polymorphisms are in linkage disequilibrium with other regulatory sequence variations that may affect gene expression or function (25). Furthermore, it has been recently reported that genes containing SNPs can cause different structural folds of mRNA (26). These mRNA variants may possess different biological functions that interact with other cellular components.

In the present study, there was a statistically significant difference between the groups of infertile women with and without endometriosis compared to the control group $(\mathrm{p}=0.0022$ and $\mathrm{p}=0.0124$, respectively) with regard to the $E R \beta+1730 \mathrm{G} / \mathrm{A}$ polymorphism, suggesting that this polymorphism might be related to infertility, particularly to endometriosis-associated infertility. The presence of only one copy of the polymorphic allele $\mathrm{A}$ leads to an increased risk of 1.91 times $(\mathrm{OR}=$ $1.91,95 \% \mathrm{CI}=1.26-2.89)$ to develop endometriosis and $1.96(\mathrm{OR}=1.96,95 \% \mathrm{CI}=1.18-3.24)$ to develop infertility in relation to the control group. When we compared infertile groups with and without endometriosis, in order to detect if the polymorphism was linked to endometriosis or infertility, there were no statistically significant differences related to the studied polymorphism frequency, suggesting that maybe endometriosis is only a coincidental finding along with infertility.

The Hardy-Weinberg equilibrium showed a light deviation for the group of infertile patients with endometriosis. HWE is an approximation, because these specific assumptions are rarely perfectly met in human populations plus a large sample is usually required to conform to the 'infinity population' requirement. Deviation from HWE tests may indicate failure in one or more assumptions such as population stratification, selection bias or genotyping error $(27,28)$. The $E R \beta$ gene $+1730 \mathrm{G} / \mathrm{A}$ polymorphism was identified by RFLP-PCR and a random subset ( $20 \%$ of samples) was repeated by qPCR to verify the results. However, only the genotype distribution of the patient group showed deviation from HWE, providing additional support for an association of the marker locus with endometriosis (29).

It is important to keep in mind that the study was performed in a special group of patients, who were operated on by videolaparoscopy and, after surgery, were exposed for at least twelve months to the possibility of pregnancy, had no male factor involved in the causes of infertility and, nevertheless, did not achieve pregnancy.

Human fertility is a complex feature determined by interactions between genetic and environmental factors. A recent series of twin studies provided evidence that genetic factors represent a significant component of human fertility measured as waiting time to pregnancy, completed family size and age at first conception (30-32). In addition, behavioral genetics studies have documented genetic influences on fertility precursors such as onset of puberty, sexual behavior and desire to have children. It would be of great interest to characterize the actual relationship between this mutation and endometriosis and/or infertility in a large number of cases. Endometriosis is found in up to $20 \%-50 \%$ of infertile women (3), but the reason why women with endometriosis have impaired fertility is uncertain and remains an area of active investigation. 
In conclusion, we found significant differences between infertile women both with and without endometriosis and controls regarding the frequencies of the $E R \beta$ gene $+1730 \mathrm{G} / \mathrm{A}$ polymorphism. Thus, our data suggest that an $E R \beta$ gene polymorphism may be associated with infertility and infertility-associated endometriosis, although endometriosis might be only a coincidental finding along with infertility. However, further studies with much larger sample sizes are needed to evaluate the true role of the $E R \beta$ gene in infertility and endometriosis.

Acknowledgments: the authors wish to thank NEPAS (Study, Research and Health Assistance Nucleus of the ABC Faculty of Medicine) for granting student Fernanda Abani Mafra a Scientific Initiation scholarship.

Disclosure: no potential conflict of interest relevant to this article was reported.

\section{REFERENCES}

1. Giudice LC, Kao LC. Endometriosis. Lancet. 2004;364:1789-99.

2. Missmer SA, Cramer DW. The epidemiology of endometriosis. Obstet Gynecol Clin North Am. 2003;30(1):1-19, vii.

3. Gao X, Outley J, Botteman M, Spalding J, Simon JA, Pashos CL. Economic burden of endometriosis. Fertil Steril. 2006;86(6):1561-72.

4. Vigano P, Somigliana E, Vignali M, Busacca M, Blasio AM. Genetics of endometriosis: current status and prospects. Front Biosci. 2007;12:3247-55.

5. Ammendola M, Bottini N, Pietropolli A, Saccucci P, Gloria-Bottini F. Association between PTPN22 and endometriosis. Fertil Steril. 2008;89(4):993-4.

6. Olive DL, Schwartz LB. Endometriosis. N Engl J Med. 1993; 328:1759-69.

7. Kuiper GG, Enmark E, Pelo-Huikko M, Nilsson S, Gustafsson JA. Cloning of a novel estrogen receptor expressed in rat prostate and ovary. Proc Natl Acad Sci USA. 1996;93:5925-30.

8. Fujimoto J, Hirose R, Sakaguchi H, Tamaya T. Expression of oestrogen receptor-alpha and -beta in ovarian endometriomata. Mol Hum Reprod. 1999;5(8):742-7.

9. Diez-Perez A. Selective estrogen receptor modulators (SERMS). Arq Bras Endocrinol Metabol. 2006;50(4):720-34.

10. Bianco B, Christofolini DM, Mafra FA, Brandes A, Zulli K, Barbosa $\mathrm{CP} .+1730 \mathrm{G} / \mathrm{A}$ polymorphism of the estrogen receptor $\beta$ gene $(E R \beta)$ may be an important genetic factor predisposing to endometriosis. Acta Obstet Gynecol Scand. 2009;88(12):1397-401.

11. Revised American Society for Reproductive Medicine classification of endometriosis: 1996. Fertil Steril. 1997;67(5):817-21.

12. Lee GH, Kim SH, Choi YM, Suh CS, Kim JG, Moon SY. Estrogen receptor beta gene $+1730 \mathrm{G} / \mathrm{A}$ polymorphism in women with endometriosis. Fertil Steril. 2007;88(4):785-8.

13. Saunders PT. Does estrogen receptor beta play a significant role in human reproduction? Trends Endocrinol Metab. 2005;16(5):222-7.

14. Couse JF, Lindzey J, Grandien K, Gustafsson JA, Korach KS. Tissue distribution and quantitative analysis of estrogen receptoralpha (ERalpha) and estrogen receptor-beta (ERbeta) messenger ribonucleic acid in the wild-type and ERalpha-knockout mouse. Endocrinology. 1997;138(11):4613-21.

15. Matthews J, Gustafsson JA. Estrogen signaling: a subtle balance between ER alpha and ER beta. Mol Interv. 2003;3(5):281-92.

16. Hewitt SC, Korach KS. Oestrogen receptor knockout mice: roles for oestrogen receptors alpha and beta in reproductive tissues. Reproduction. 2003;125(2):143-9.

17. Corbo RM, Ulizzi L, Piombo L, Martinez-Labarga C, De Stefano GF, Scacchi R. Estrogen receptor alpha polymorphisms and fertility in populations with different reproductive patterns. Mol Hum Reprod. 2007;13(8):537-40.

18. Krege JH, Hodgin JB, Couse JF, Enmark E, Warner M, Mahler JF, et al. Generation and reproductive phenotypes of mice lacking estrogen receptor beta. Proc Natl Acad Sci USA. 1998;95(26):15677-82.

19. Scobie GA, Macpherson S, Millar MR, Groome NP, Romana PG, Saunders PT. Human oestrogen receptors: differential expression of ER alpha and beta and the identification of ER beta variants. Steroids. 2002;67(12):985-92.

20. Critchley HO, Henderson TA, Kelly RW, Scobie GS, Evans LR, Groome NP, et al. Wild-type estrogen receptor (ERbeta1) and the splice variant (ERbetacx/beta2) are both expressed within the human endometrium throughout the normal menstrual cycle. J Clin Endocrinol Metab. 2002;87(11):5265-73.

21. Kayisli UA, Guzeloglu-Kayisli O, Arici A. Endocrine-immune interactions in human endometrium. Ann NY Acad Sci. 2004;1034:50-63.

22. Critchley HO, Brenner RM, Henderson TA, Williams K, Nayak NR, Slayden OD, et al. Estrogen receptor beta, but not estrogen receptor alpha, is present in the vascular endothelium of the human and nonhuman primate endometrium. $\mathrm{J}$ Clin Endocrinol Metab. 2001;86(3):1370-8.

23. Enmark E, Pelto-Huikko M, Grandien K, Lagercrantz S, Lagercrantz J, Fried G, et al. Human estrogen receptor b gene structure, chromosomal localization, and expression pattern. J Clin Endocrinol Metab. 1997;82(12):4258-65.

24. Rosenkranz K, Hinney A, Ziegler A, Hermann H, Fichter M, Mayer $\mathrm{W}$, et al. Systemic mutation screening of the estrogen receptor beta gene in probands of different weight extremes: identification of several genetic variants. J Clin Endocrinol Metab. 1998;83(12):4524-7.

25. Yaich L, Dupont WD, Cavener DR, Parl FF. Analysis of the Pvull restriction fragment length polymorphism and exon structure of the estrogen receptor gene in breast cancer and peripheral blood. Cancer Res. 1992;52(1):77-83.

26. Shen LX, Basilion JP, Stanton Jr VP. Single-nucleotide polymorphisms can cause different structural folds of mRNA. Proc Natl Acad Sci USA. 1999;96(14):7871-6.

27. Hosking L, Lumsden S, Lewis K, et al. Detection of genotyping errors by Hardy-Weinberg equilibrium testing. Eur J Hum Genet. 2004;12:395-9.

28. Salanti G, Amountza G, Ntzani EE, loannidis JP. Hardy-Weinberg equilibrium in genetic association studies: an empirical evaluation of reporting, deviations, and power. Eur J Hum Genet. 2005;13(7):840-8.

29. Esser C, Tomiuk J. Reporting Hardy-Weinberg tests in case-control studies: reasons for caution but not for panic reactions. $\mathrm{J}$ Invest Dermatol. 2005;124(5):1082-3.

30. Rodgers JL, Kohler HP, Kyvik KO, Christensen K. Behavior genetic modeling of human fertility: findings from a contemporary Danish Twin Study. Demography. 2001;38(1):29-42.

31. Christensen K, Kohler HP, Basso O, Olsen J, Vaupel JW, Rodgers $\mathrm{JL}$. The correlation of fecundability among twins: evidence of a genetic effect on fertility? Epidemiology. 2003;14(1):60-4.

32. Kohler HP, Rodgers JL, Miller WB, Skytthe A, Christensen K. Biosocial determinants of fertility. Int J Androl. 2006;29(1):46-53. 